\title{
AGENDA SETTING HARIAN TRIBUN BATAM DALAM PEMBERITAAN IMPLEMENTASI KAWASAN EKONOMI KHUSUS
}

\author{
Ageng Rara Cindoswari ${ }^{1)}$, Sholihul Abidin' ${ }^{2)}$, Hendri Herman ${ }^{3)}$ \\ ${ }^{1)}$ Dosen Prodi Ilmu Komunikasi, Universitas Putera Batam, \\ ${ }^{2)}$ Dosen Prodi Ilmu Komunikasi, Universitas Putera Batam \\ ${ }^{3)}$ Dosen Prodi Manajemen, Universitas Putera Batam \\ Email:cindoswari@gmail.com
}

\begin{abstract}
The agenda of setting media is the media directing the public what is the main issue and perceived by the public as the main issue. The agenda setting concept recognizes three agendas, namely the media agenda, the public agenda, and the policy agenda. Type This research is descriptive research with quantitative approach and survey method. Location and object of research is selected purposively (deliberately) where the City of Batam is a city given the privilege of the status of the region that is Special Economic Zone (KEK). The sample was 399 people determined by cluster random sampling. The research was conducted by spreading the questionnaire and analyzed by Rank Spearman correlation. The result of this research shows that 63,4\% of SEZ implementation report in Batam Tribun Daily has high media agenda, 74,2\% contains high enough public agenda.
\end{abstract}

Keywords: Agenda Setting, Daily Tribune Batam, KEK Implementation.

\section{PENDAHULUAN}

Perubahan kebijakan pembangunan ekonomi mengenai penetapan kawasan batam mengalami dilematis ketika batam yang memiliki "brand" sebagai kawasan Free Trade Zone namun saat ini telah berganti menjadi Kawasan Ekonomi Khusus. Beberapa implikasi dari penetapan kebijakan ekonomi terdapat pada perubahan tata ruang dan infrastruktur; insentif dan pembiayaan; kelembagaan dan hukum pada praktek kepabean, pajak, ijin, imigrasi dan ketenaga kerjaan dalam mengelola arus perdagangan dan peredaran barang di Kota Batam. Kompleksnya konsekuensi yang ditimbulkan oleh perubahan kebijakan ini akan berdampak pada masyarakat secara luas, dimana masyarakat perlu mendapatkan kejelasan dan kepastian informasi mengenai segala bentuk perubahan berserta dengan konseskuensi dan penerapaannya di lapangan. Pada konteks persoalan mengenai kejelasan dan kepastian terkait informasi Kawasan Ekonomi Khusus inilah media massa dapat mengambil peran sebagai perantara yang menjembatani pemerintah dan masyarakat dalam aspek pertukaran informasi, merangsang partisipasi aktif masyarakat baik dalam implementasi maupun pengawasan kebijakan KEK.

Menurut Mc Quail (2009) peran media massa diantaranya adalah (1) jendela informasi, (2) cermin peristiwa masyarakat dan dunia, (3) filter / gatekeeper, (4) guidedan interpreter, (5) forum dan umpan balik, (6) interlocutor (partner komunikasi). Hadirnya 


\section{Vol. 2 No.1 Agustus 2017}

media pada konteks pembangunan ekonomi melalui kebijakan Kawasan Ekonomi Khusus berdampak pada pembentukan persepsi masyarakat dalam merespon kebijakan tersebut. Umumnya pemberitaan media massa berkorelasi pada tataran persepsi bukan pada sikap ataupun tindakan individu. Terdapat pengaruh yang signifikan antara pemberitaan media massa dengan pembentukan persepsi khalayak. Hal ini dibuktikan pada penelitian teori agenda setting tahap awal berdasarkan mahzab positivistik. Pengaruh yang signifikan ini terlihat dari bagaimana media membuat agenda dengan memberitakan hal yang tidak hanya dianggap penting oleh mereka tetapi juga dianggap penting oleh khalayak sehingga media menentukan kemana arah khalayak seharusnya berfikir dan berfikir mengenai apa. Individu yang terpapar (expose) media massa memiliki persepsi yang cenderungan nyata untuk menerima pemberitaan media massa sebagai realitas.

Tidak banyak penelitian media massa dengan menggunakan teori agenda setting dalam menganalisis fenomena pembangunan. Beberapa penelitian yang telah dilakukan sangat erat kaitannya dengan isu politik terkat dengan pilpres, pilkada, dan isu-isu politik sejenis. Selanjutnya, tidak banyak pula media massa yang memiliki kenetralan dalam pemberitaan. Beberapa koran (media massa cetak) nasional merupakan rekanan abadi pemerintah sehingga pemberitaan mengenai kebijakan pemerintah cenderung tidak "cover both side". Harian Tribun merupakan salah satu harian lokal yang masih cenderung netral dalam pemberitaan terkait kebijkan pemerintah. Penelitian ini mencoba untuk melihat sisi lain dari media massa dalam membingkai isu pembangunan ekonomi (Implementasi KEK) melalui perannya sebagai perantara antara pemerintah, masyarakat dan stakeholders lainnya yang dianalisis berdasarkan keragaan agenda setting media pada pemberitaan Kawasa Ekonomi Khusus Di Kota Batam.

Rumusan masalah dalam penelitian ini adalah:

1. Bagaimanakah deskripsi agenda media pada Harian Tribun Batam dalam pemberitaan implementasi kebijakan Kawasan Ekonomi Khusus?

2. Bagaimanakah deskripsi agenda publik media Harian Tribun Batam dalam pemberitaan implementasi kebijakan Kawasan Ekonomi Khusus?

\section{METODOLOGI PENELITIAN}

Jenis Penelitian ini adalah penelitian deskriptif dengan pendekatan kuantitatif dan metode survei. Penelitian kuantitatif merupakan penelitian yang diperoleh dengan mengukur nilai satu atau lebih variabel dalam sampel. Metode. Penelitian survei adalah penelitian yang mengambil yang mengambil sampel dari satu populasi dan menggunakan 


\section{Vol. 2 No.1 Agustus 2017}

kuesioner sebagai alat pengumpulan data yang pokok, (Sugiyono, 2010).

Lokasi dan objek penelitian dipilih secara purposive (sengaja) dimana Kota Batam merupakan kota yang diberikan keistimewaan status kawasan yakni Kawasan Ekonomi Khusus (KEK). Penelitian ini dilakukan pada warga Kota Batam yang memiliki akses terhadap media massa cetak yakni Harian Tribun.

Data yang dikumpulkan diolah dan dianalisis berdasarkan kepentingan penelitian. Dalam penelitian ini teknik analisis data yang digunakan adalah Analisis Statistik yakni Rank Spearman menggunakan program SPSS 20 for windows. Untuk menganalisis tingkat agenda media, agenda public, menggunakan lima jumlah kelas yaitu sangat setuju sekali, setuju sekali, setuju, tidak setuju, sangat tidak setuju sekali dengan diberi skor tertinggi dan skor terendah .Rumus yang digunakan untuk mengukur tingkat adaptasi adalah:

$$
\begin{aligned}
& \mathrm{NR}=\mathrm{NST}-\mathrm{NSR} \\
& \mathrm{PI}=\mathrm{NR}: \mathrm{JIK}
\end{aligned}
$$

Keterangan :

NR : Nilai Range

NST : Nilai Skor Tertinggi

NSR : Nilai Skor Terendah

JIK : Jumlah Interval Kelas

PI : Panjang Interval

\section{HASIL DAN PEMBAHASAN}

\section{Karakteristik Responden Penelitian}

Berdasarkan kriteria jenis kelamin responden penelitian ini lebih banyak di dominasi oleh perempuan.Jumlah diketahui bahwa responden perempuan lebih banyak daripada responden laki-laki. Jmlah responden perempuan sebanyak 256 sementara laki-laki 143. Jika diprosentasikan maka jumlah responden perempuan sebanyak 64,1 persen atau terdapat selisih 28,3 persen dari responden laki-laki sejumlah 35,8 persen.

\section{Pendidikan menurut Notoatmodjo} (2010) memiliki pengaruh kognitif seseorang dalam peningkatan pengetahuan. Karena pengetahuan sebenarnya tidak dibentuk hanya satu sub saja yaitu pendidikan tetapi ada sub bidang lain yang akan juga akan mempengaruhi pengetahuan seseorang misalnya pengalaman, informasi, keperibadian dan lainya. Dalam penelitian ini profil responden dikategorisasikan pada empat kelmpok. Pertama adalah responden yang memiliki tingkat pendidikan dari SD sampai SMP, Kedua SMU, ketiga Strata 1 dan keempat adalah Strata 2.

Berdasarkan kriteria pendidikan yang menjadi responden dalam penelitian ini adalah tingkat pendidian mulai dari Sekolah Dasar hingga Perguruan Tinggi tingkat Magister. Responden berdasarkan kriteria pendidikan paling banyak adalah responden yang memiliki tingkat pendidikan Sekolah Menengah Atas atau sederajat yaitu 276 orang atau sebanyak 69,1 persen. Persentase ini menunjukkan selisih yang sangat tinggi dari persentase responden terkecil dengan tingkat 
pendidikan strata 2 atau Magister yang hanya 1 orang atau 0,2 persen, yaitu 68,9 persen yang menunjukkan lebih dari separuh seluruh persentase responden penelitian.

Berdasarkan klasifikasi pekerjaan respondendapat diketahui bahwa persentase tertinggi adalah swasta, yaitu sebanyak 42,3persen. Persentase responden berdasar klasifikasi pekerjaan karyawan swasta ini termasuk cukup tinggi dari kriteria pekerjaan terendah responden, yaitu Pegawai Negeri Sipil yang hanya sebanyak 1,7 persen.Dari segi jumlah kriteria pekerjaan responden sebagai karyawan swasta ini sebanyak 169 orang. Sedangkan jumlah responden berdasarkan kriteria pekerjaan sebagai Pegawai Negeri Sipil hanya sejumlah 7 orang dari jumlah keseluruhan responden. Terdapat selisih jumlah responden sebanyak 162 orang responden antara swasta dan Pegawai Negeri Sipil sebagai responden dalam penelitin ini.

Kebutuhan akan informasi yang disajikan dalam bentuk berita dapat diperoleh melalui berbagai media. Media cetak merupakan media yang dinilai lebih terpercaya dalam memberikan informasi dibandingkan media lainnya. Masyarakat di Kota Batam dalam mencari berita masih mengandalkan media massa cetak khususnya dalam penelitian ini adalah Harian Tribun Batam. Masyarakat Kota Batam dalam penelitian ini memiliki perilaku kecenderungan tertentu dalam mengakses berita melalui media massa.
Khusus media massa Koran Harian Tribun Batam, responden menunjukkan perbedaan perilaku yang berbeda untuk setiap berita yang mereka baca. Untuk lebih jelas mengenai perbedaan kecenderungan perilaku akses berita dalam bentuk persentase dapat dilihat pada tabel dibawah ini.

Tabel 3.1. Jumlah dan Persentase Responden Berdasarkan Perilaku Akses Media

\begin{tabular}{llcc}
\hline $\begin{array}{c}\text { Perilaku Akses } \\
\text { Media }\end{array}$ & \multicolumn{1}{c}{ Kategori } & Jumlah & $\begin{array}{c}\text { Persentase } \\
(\%)\end{array}$ \\
\hline Pilihan Berita & Ekonomi & 261 & 65,4 \\
& Politik & 52 & 13,0 \\
& Olah Raga & 39 & 9,8 \\
& Hukum & 20 & 5,0 \\
& Hiburan & 27 & 6,8 \\
\hline Frekuensi Mengakses & 1 minggu sekali & 133 & 33,3 \\
(kali/minggu) & 1 minggu 2 kali & 83 & 20,8 \\
& 1 minggu 3 kali & 63 & 15,8 \\
& 1 minggu 4 kali & 42 & 10,5 \\
& Setiap hari & 78 & 19,5 \\
\hline Durasi Mengakses & Setengah jam & 26 & 6,5 \\
(jam/minggu) & 1 jam & 103 & 25,8 \\
& Satu setengah jam & 15 & 3,8 \\
& Dua jam & 14 & 3,5 \\
& Dua setengah jam & 7 & 1,8 \\
\hline
\end{tabular}

Sumber : Data primer diolah, 2017

Berdasarkan tabel di atas dapat dilihat bahwa perilaku mengakses berita responden penelitian terbagi menjadi 3 kategori yakni pilihan berita, frekuensi mengakses media dan durasi mengakses media. Masing-masing kategori menunjukkan persentase yang berbeda hal ini terlihat pada pilihan berita yang paling menonjol dipilih oleh responden adalah berita ekonomi sebesar 65,4 persen, frekuensi mengakses 1 minggu sekali sebesar 33,3 persen dan durasi membaca selama 1 jam 
sebesar 25, 8 persen. Berdasarkan data diatas terlihat bahwa minat membaca masyarakat kota batam tersita pada berita-berita yang menginformasikan tentang perkembangan ekonomi, termasuk diantaranya adalah berita terkait dengan perkembangan perubahan kebijakan pembangunan ekonomi dari Free Trade Zone ke Kawasan Ekonomi Khusus. Adapun berita lainnya yang banyak dicari adalah berita mengenai politik.

Frekuensi mengakses dan durasi mengakses menunjukkan tingkat keaktifan responden dalam mencari berita pada media massa. Data mengenai sakses media massa jugamemberikan gambaran karakteristik kemampuan dan kebutuhan dalam mencari berita yang berujung padatingkat literasi media. Berdasarkan data diatas terlihat bahwa mayoritas responden penelitian mengakses media hanya 1 minggu sekali dan berdurasi selama 1 jam. Dengan karakteristik seperti itu dapat terlihat bahwa perilaku mengakses media masyarakat kota batam tidak cukup baik, dimana frekuensi dan durasi seperti itu cukup memprihatinkan bagi tingkat literasi media di sebuah daerah. Namun, kondisi seperti ini dapat disebabkan oleh beberapa hal, diantaranya adalah mulai beralihnya media massa cetak ke media online. Arus globalisasi dan perkembangan teknologi digital turut mempengaruhi perilaku mengakses media dalam versi yang berbeda. Literasi media yang rendah pada media cetak namun sebaliknya pada literasi media yang tinggi pada media online.

\section{Agenda Media Harian Tribun Batam Pada Pemberitaan Implementasi Kawasan Ekonomi Khusus Di Kota Batam}

Setiap Media massa memiliki agenda masin-masing untuk dapat mengarahkan apaapa saja yang perlu dianggap penting untuk dipikirkan atau dipersepsikan oleh audiensnya. Tujuan agenda media adalah memberikan pengaruh pada perubahan kognitif antar individu. Media sukses memberitahu publik mengenai apa yang seharusnya mereka pikirkan. Tedapat korelasi yang sempurna antara isu apa yang dianggap penting oleh khalayak dengan topik yang di beritakan pada media. Terdapat relasi yang kuat antara penekanan pada isu oleh media dengan penilaian audien tentang kemenonjolan dan arti penting isu-isu yang dikampanyekan (agenda publik). Agenda media digerakkan oleh pasar (melalui rating, studi audiensi, riset pasar dan pola konsumsi) sehingga menyediakan apa-apa yang dapat dijual ke audien.

Agenda memainkan peranan penting dalam menciptakan opini publik dan mengkonstruksi realitas sosial yang terjadi. Dalam penerapannya agenda media memiliki beberapa dimensi yang meliputi visibialitas, relevansi dan valensi. Visiabilitas yaitu jumlah dan tingkat menonjolnya berita, tingkat menonjol bagi khalayak, relevansi isi berita dengan kebutuhan khalayak, dan valensi yakni 
menyenangkan atau tidak menyenangkan cara pemberitaan bagi suatu peristiwa. Pemberitaan mengenai perubahan kebijakan ekonomi di Kota Batam dari Free Trade Zone ke Kawasan Ekonomi Khusus tentunya merupakan salah satu bagian dari agenda media pada media itu sendiri. Penonjolan beberapa berita mengenai Kawasan Ekonomi Khusus yang diberitakan oleh Harian Tribun Batam yang di nilai oleh pembacanya tergambarkan pada tabel dibawah ini.

Tabel 3.2. Sebaran Agenda Media Harian Tribun Batam Pada Pemberitaan KEK Berdasarkan Penilaian Responden

\begin{tabular}{|l|c|c|c|}
\hline \multicolumn{1}{|c|}{ Kategori } & Interval & Jumlah & Persentase \\
\hline $\begin{array}{l}\text { Sangat Tidak } \\
\text { Setuju }\end{array}$ & $8-13$ & 3 & 0,8 \\
\hline Tidak Setuju & $14-19$ & 70 & 17,5 \\
\hline Setuju & $20-25$ & 253 & 63,4 \\
\hline $\begin{array}{l}\text { Sangat } \\
\text { Setuju }\end{array}$ & $26-31$ & 69 & 17,3 \\
\hline $\begin{array}{l}\text { Sangat Setuju } \\
\text { Sekali }\end{array}$ & $>32$ & 4 & 1,0 \\
\hline \multicolumn{2}{|c|}{ Total } & $\mathbf{3 9 9}$ & $\mathbf{1 0 0}$ \\
\hline
\end{tabular}

Sumber : Data primer diolah, 2017

Berdasarkan Tabel di atas dapat dilihat bahwa penilaian pembaca harian tribun batam terhadap pemberitaan Kawasan Ekonomi Khusus memiliki nilai visiabilitas, relevansi dan valensi sebesar 63,4 persen berada pada kategori setuju. Artinya lebih dari 50\% pembaca Harian Tribun Batam setuju bahwa pemberitaan Kawasan Ekonomi Khusus yang memiliki penonjolan berita yang cukup.Selanjutnya pemberitaan Kawasan
Ekonomi Khusus di Harian Tribun juga dinilai cukup memenuhi kebutuhan pembaca serta memiliki penyajian yang menyenangkan bagi pembaca. hal ini juga terlihat dari observasi terhadap harian Tribun Batam dimana selama 10 bulan yakni mulai Desember 2016 hingga Oktober 2017 terdapat kurang lebih 100 berita terkait dengan pemberitaan Kawasan Ekonomi Khusus. Hal ini menggambarkan bahwa perubahan FTZ menjadi Kawasan Ekonomi Khusus di Kota Batam mendapatkan perhatian yang cukup menonjol seiring dengan kebutuhan pembaca dalam mencari berita tersebut.

\section{Agenda Publik Harian Tribun Batam Pada Pemberitaan Implementasi Kawasan Ekonomi Khusus Di Kota Batam}

Agenda publik merupakan hal-hal yang diangga penting oleh khalayak. Agenda publik menentukan kemana agenda media ditentukan.Agenda publik juga terkadang menjadi orientasi dari agenda media. Berdasarkan teori agenda setting pada media massa, agenda publik memiliki dimensi yang meliputi keakraban yaitu kesadaran khalayak akan topik tertentu, penonjolan pribadi yaitu relevansi kepentingan individu dengan ciri pribadi, dan kesenangan yaitu pertimbangan senang atau tidak senang akan topik berita.Berikut ini disajikan penilaian responden penelitian terhadap muatan agenda publik yang terdapat pada pemberitaan KEK di Kota Batam pada Harian Tribun Batam. 


\section{Vol. 2 No.1 Agustus 2017}

Tabel 3.3. Sebaran Agenda Publik Harian Tribun Batam Pada Pemberitaan KEK Berdasarkan Penilaian Responden

\begin{tabular}{|l|c|c|c|}
\hline \multicolumn{1}{|c|}{ Kategori } & Interval & Jumlah & Persentase \\
\hline $\begin{array}{l}\text { Sangat Tidak } \\
\text { Setuju }\end{array}$ & $6-10$ & 3 & 0,8 \\
\hline Tidak Setuju & $11-15$ & 34 & 8,5 \\
\hline Setuju & $16-20$ & 296 & 74,2 \\
\hline Sangat Setuju & $21-25$ & 60 & 15,0 \\
\hline $\begin{array}{l}\text { Sangat Setuju } \\
\text { Sekali }\end{array}$ & $>26$ & 6 & 1,5 \\
\hline \multicolumn{2}{|c|}{ Total } & $\mathbf{3 9 9}$ & $\mathbf{1 0 0}$ \\
\hline
\end{tabular}

Sumber : Data primer diolah, 2017

Berdasarkan tabel diatas dapat dilihat sebaran penilaian agenda publik yang muncul pada pemberitaan Kawasan Ekonomi Khusus di Harian Tribun. Sebanyak 74, 2 persen masyarakat setuju bahwa agenda publik muncul pada pemberitaan Kawasan Ekonomi Khusus di Harian Tribun Batam. Harian Tribun batam cukup merepresentasi agenda publik dari sisi kebutuhan informasi terkait implementasi Kawasan Ekonomi Khusus. Agenda publik yang tergambarkan pada Harian Tribun Batam yang paling menonjol adalah familiarity dan favoriability. Familiarity menunjukkan kesadaran khalayak akan topik tertentu sedangkan favorability menujukkan senang atau tidaknya mereka pada pemberitaan. Sedangkan relevansi kepentingan personal salience tidak begitu muncul pada observasi yang dilakukan oleh peneliti.
Data yang tersaji pada tabel diatas juga menunjukkan bahwa Harian Tribun sudah cukup baik dalam merepresentasikan kebutuhan pembacanya yang tercermin pada agenda publik pada pemberitaan Kawasan Ekonomi Khusus tersebut. Masyarakat Kota Batam dalam hal ini responden penelitian cukup memahami dalam melihat pemberitaan Kawasan Ekonomi Khusus.Hal ini didukung dengan data perilaku akses media yang tersaji pada tabel 4.6 di atas yang menunjukkan kecenderungan minat pembaca mencari berita ekonomi. Sehingga, tingkat literasi masyarakat cukup baik dan mempengaruhi pemahaman mereka terhadap pemberitaan Kawasan Ekonomi Khusus di Harian Tribun.

\section{Implementasi Kawasan Ekonomi Khusus Di kota Batam dan Perspektif Media Massa Cetak Harian Tribun Batam.}

Implementasi Kawasan Ekonomi

Khusus sendiri sebagai bentuk solusi perubahan sistem ekonomi di kota Batam merupakan solusi yang tepat. Dengan catatan sepanjang tidak meghapus konsep Free Trade Zone yang sudah ada dan berlaku selama 70 tahun. Selain itu, adanya implementasi Kawasan Ekonomi Khusus ini akan menghapus tumpang tindih kewenangan antara Badan Pengusahaan (BP) Batam dan Pemerintah Kota (Pemko) Batam. Implementasi Kawasan Ekonomi Khusus sendiri sebenarnya bukan tanpa alasan.Pertumbuhan ekonomi di Batam yang mengalami penurunan secara drastis seiring 


\section{Vol. 2 No.1 Agustus 2017}

menurunnya ekonomi global membuat pemerintah melakukan perubahan kebijakan ekonomi dengan mengimplementasikan Kawasan Ekonomi Khusus sebagai pengganti sistem ekonomi Free Trade Zone .Perubahan tersebut dilakukan dengan melihat melihat banyak sekali celah kekurangan dalam konsep Free Trade Zone Batam serta semakin menurunnya daya saing Batam sebagai tujuan investasi asing dimana insentif yang ditawarkan Free Trade Zone sudah semakin tidak menarik bagi calon investor.Hanya saja penilaian terhadap implementasi Kawasan Ekonomi Khusus di Batam ini belum dapat dilakukan penilaian karena pemerintah baru meresmikan Kawasan Ekonomi Khusus di Batam pada Maret 2017. Sehingga belum terlihat progres dari implementasi kebijakan perubahan sistem Kawasan Ekonomi Khusus.Ada beberapa manfaat serta dampakdampak yang dapat dilihat dari implementasi Kawasan Ekonomi Khusus di Batam.

Salah satu manfaat dengan berlakunya Kawasan Ekonomi Khusus diantaranya adalah kemudahan berbisnis serta insentif bagi investor diluar daripada insentif yang telah didapat selama penerapan sistem Free Trade Zone menjadi daya tawar dari implementasi Kawasan Ekonomi Khusus bagi para investor.Implementasi Kawasan Ekonomi Khusus di Batam juga menjadi solusi bagi tumpang tindih kewenangan antara pemerintah administratif atau pemerintah daerah yang dalam hal ini adalah Pemko Batam dengan BP Batam sebagai pengelola aset-aset strategis dan perekonomian di Batam. Selanjutnya manfaat implementasi Kawasan Ekonomi Khusus tergambar pada pernyataan naraasumber berikut :

"Sebetulnya ada manfaatnya lah dengan system Kawasan Ekonomi Khusus ini seperti kemudahan dan insentif plus-plus bagi calon investor diluar insentif Free Trade Zone yang sudah ada...trrus bias juga menghilangkan tumpang tindih kewenangan perizianan karena pembagian wilayah kerja dan kewenangan yang sangat jelas antara BP Batam dan Pemko Batam..."(Mgi, didokumentasikan April 2017).

Konsistensi implementasi Kawasan Ekonomi Khusus perlu komitmen yang tinggi dari pemerintah pusat sehingga kemudahan serta insentif plus plus dari konsep Kawasan Ekonomi Khusus Batam dapat diterima oleh dunia usaha dan industri.Komitmen ini harus benar-benar dilakukan untuk meningkatkan kembali daya saing Batam sebagai tujuan investasi asing.Dengan adanya implementasi Kawasan Ekonomi Khusus ini sebenarnya menguntungkan bagi stakeholder seperti pelaku usaha, pemerintah pusat, Pemprov kepulauan Riau, Pemerintah Kota Batam, Badan Pengusahaan Batam. Kebijakan ini juga dapat meminimalisir atau bahkan memotong aktifitas dari para spekulan lahan serta calo perizinan karena dengan adanya Kawasan Ekonomi Khusus menjanjikan kemudahan birokrasi dalam perizinan yang semakin cepat dan mudah. 


\section{Vol. 2 No.1 Agustus 2017}

Segala sesuatu kebijakan baru atau system baru pasti memiliki dua sisi dampak baik positif maupun negatif.Implementasi Kawasan Ekonomi Khusus juga memiliki dampak negatif selain dampak positif diantaranya adalah (1). Kawasan Ekonomi Khusus sudah pernah diterapkan di Batam dan mengalami kegagalan, Artinya penerapan KEK sat ini juga dapat mengalami kegagalan seperti yang pernah diterapkan pada waktu sebelumnya, (2). Berpeluang munculnya pemaksaan relokasi bagi pelaku industri untuk masuk ke dalam Kawasan Ekonomi Khusus. Namun sepanjang pemaksaan itu tidak terjadi maka implementasi KEK tidak mengganggu dunia industri di Batam, (3).Hilangnya Free Trade Zone yang sudah diterapkan selama bertahun-tahun. Substansi Free Trade Zone yang sudah diterapkan tidak perlu untuk dihilangkan.Artinya, kebijakan implementasi Kawasan Ekonomi Khusus menjadi pendukung atas kekurangan dari implementasi Free Trade Zone yang dirasa kurang mampu menjawab kebutuhan dunia industri dan usaha.

Jika kita mencermati kondisi perekonomian di Batam yang menurun drastis bahkan dapat dikatakan kolaps seperti saat ini, implementasi dari konsep Kawasan Ekonomi Khusus ini harus sudah melalui hasil uji yang benar-benar matang dan siap dengan segala peluangnya. Artinya, implementasi Kawasan Ekonomi Khusus ini bukan sekedar spekulasi kebijakan untuk belajar apalagi percobaan untuk konsep baru.Komitmen pemerintah dalam implementasi Kawasan Ekonomi Khusus di Batam benar-benar dijaga dari pergantian periode kepengurusan atau kepemimpinan pemangku kebijakan supaya dapat memberikan jaminan atau kepastian bagi dunia investasi, dunia usaha dan industri di Batam.Sekaligus membangun aliansi strategis dengan kawasan sejenis di regional demi terciptanya hubungan kerjasama yang saling menguntungkan.Terdapat beberapa hal yang perlu menjadi catatan penting dalam implementasi Kawasan Ekonomi Khusus di batam diantaranya adalah (1).Antisipasi dari banyaknya komoditas hasil industri yang rembes keluar dari kawasan Kawasan Ekonomi Khusus, (2). Meningkatkan aspek pengawasan dengan ketat terhadap arus lalu lintas al in yang masuk dan keluar dari Kawasan Ekonomi Khusus, (3). Pembagian kewenangan dan wilayah kerja yang jelas antara BP Batam dan Pemko Batam agar tidak terjadi tumpang tindih kewenangan.Utamanya dalam hal perizinan, (4).Pengawasan yang ketat yang tidak membuat birokrasi lalu lintas barang keluar masuk Kawasan Ekonomi Khusus menjadi sulit.Hal ini juga dipertegas melalui pernyataan narasumber dari Ketua Time Ekonomi Kadin Batam berikut ini.

"Kalo memang pemerintah punya komitmen dalam menerapkan Kawasan Ekonomi Khusus maka segala sesutunya harus jelas sehing ada hal-hal pokok yang menjadi catatan penting misalnya pembagian 
kewenangan dan tugas yang jelas antara BP Batam dan Pemkot khususnya dalam perizinan....trus harus ada pengawasan yang baik tetapi tidak mengakibatkan sulitnya keluar masuk barang diwilayah Kawasan Ekonomi Khusus ini...."(Mgi, didokumentasikan April 2017).

Tribun Batam sebagai salah satu sumber informasi bagi masyarakat Kota Batam merasa sangat penting untuk bisa memberitakan perubahan Kawasan Ekonomi Khusus ini kepada masyarakat.Tribun merasa bahwa fungsi media bukan saja memberikan informasi namun juga menjalankan fungsi pengawasan dan edukasi bagi masyarakat. Masyarakat Kota Batam berhak dan harus tau tentang segala sesuatu yang terjadi di kotanya, terutama perubahan dalam kebijakan ekonomi.Hal ini wujudkan dengan karakteristik dan strategi pemberitaan Kawasan Ekonomi Khusus di Tribun. Dapat diketahui bahwa 1 tahun belakangan ini tribun cukup intens menerbitkan berita menegenai Kawasan Ekonomi Khusus, setidaknya kurang lebh 100 berita dengan berbagai judul berita yang telah diberitakan. Hal ini dapat disimak dari pernyataan narasumber berikut ini :

"Untuk KEK sih kita beritakan secara berimbang sih ...untuk jumlah berita yang terbit ada dari sisi BP Batam ada juga dari sisi Pemkot, itu pun kami terbitkan tidak hanya pada versi cetak tetapi juga versi onlie"(Sm, didokumentasikan Mei 2017).

Harian Tribun Batam memiliki agenda media yang tidak memihak pada siapapun, dan sebagai manifestasinya mereka memiliki catatan penting dalam menyoroti perubahan Free Trade Zone ke Kawasan Ekonomi Khusus yakni mengenai dualism kepemimpinan di Kota Batam. Menurut mereka penerapan Kawasan Ekonomi Khusus ini harus dicermati mulai dari struktur kewenangan, regulasi dan kebijakan yang jelas.Hanya terdapat 2 kemungkinan dalam menyikapi dualism pemerintahan di batam yakni (1). BP Batam berada dibawah kewenanagan Pemkot atau (2). Pembubaran BP Batam secara penuh, dimana pegawai atau staf nya menjadi pegawai/staf Pemkot.Dua alternatif ini perlu dibicarakan secara baikbaik dengan perhitungan yang matang.Mereka juga melihat persoalan mengenai kewenangan tidak bisa diatasi dengan hanya mengganti pada personel saja namun yang perlu diselesaikan adalah masalah struktur. Selanjutnya, implementasi Kawasan Ekonomi Khusus saat ini masih berjalan ditempat. Belum terlalu terlihat secara jelas dan sistematis tahapan apa selanjutnya akan dilakukan dengan penerapan Kawasan Ekonomi Khusus ini. Hal ini juga tergambar pada pernyataan narasumber berikut :

"Kalo kami melihat memang perlu penataan ulang sih di batam ini...dan penataan ulang ini jangan hanya mengganti orang-orangnya saja karena masalah Kawasan Ekonomi Khusus atau dualism kepemimpinan gak akan selesai klo hanya begitu saja...perlu rombak total sehingga konsep perkembangan kota batam arahnya menjadi jelas..." (Sm, didokumentasikan Mei 2017). 


\section{Vol. 2 No.1 Agustus 2017}

\section{PENUTUP}

\section{Simpulan}

1. Penilaian responden pada agenda setting yang memuat agenda media dana agenda publik Harian Tribun Batam pada pemberitaan implementasi Kawasan Ekonomi Khusus sebagian besar atau lebih dari setengah responden menyatakan cukup tinggi.

2. Implementasi Kawasan Ekonomi Khusus di Kota batam belum terdapat perkembangan yang signifikan saat ini, namun jika nantinya dilaksanakan diperlukan pengawasan yang sesuai dalam mengatur dan mengelola hal tersebut . Media massa perlu terus mengawali proses ini dengan pemberitaan yang berimbang antara agenda media dan agenda publik.

\section{Saran}

1. Bagi yang akan melakukan penelitian sejenis, disarankan agar memilih media massa yang berbeda dalam milai agenda setting media di Kota Batam pada pemberitaan implementasi Kawasan Ekonomi Khusus, sehingga nantinya dapat menjadi pembanding antar media massa di Kota Batam dalam menginformasikan implementasi Kawasan Ekonomi Khusus di Kota Batam.
2. Bagi praktisi media massa, frekuensi pemberitaan KEK disarankan agar lebih intens dalam menyajikan pemberitaan apabila menghendaki adanya edukasi terhadap pembaca mengenai implementasi KEK di Kota Batam.

\section{DAFTAR PUSTAKA}

Adler, R.B., \& Rodman G. 2009. Understanding Human Communication. New York : Holt, Tinehart and Winston.

Amirin, Tatang M. 2009. Penelitian eksploratif.

Tatangmanguny.wordpress.com. diakses tanggal 10 Aprl 2016.

Arifin, Anwar.2010. Opini Publik. Depok : Gramata Publishing.

Creswell, John W. 2010. Research Design (Pendekatan Kualitatif, Kuantitatif, dan Mixed). Yogyakarta : Pustaka Pelajar.

Flanagin, A.J., Metzger, M.J. 2000. Perceptions of Internet Information Credibility Massachusetts: Journalism \& Mass Communication.

Kriyantono, Rachmat. 2009. Teknik Praktis Riset Komunikasi. Jakarta: Kencana Group.

McQuail, Dennis. 2009. Mass Communication Theory. London : Stage Publication, Ltd.

Mulyana, Dedy.2000. Ilmu Komunikasi, Pengantar. Bandung : Remaja Rosdakarya.

Nimmo, Dan. 2008. Komunikasi Politik. Bandung : Remaja Rosdakarya.

Nurudin, M.Si. 2007. Pengantar Komunikasi Massa. Jakarta : Raja Grafindo Persada.

Vivian, John. 2008. Teori Komunikasi Massa. Jakarta : Kencana.

http://blogs.worldbank.org/developmenttalk/chi na-s-special-economic-zones-andindustrial-clusters-success-andchallenges; 
Purba, Pandapotan T. 2015. Bappenas Call For Paper And International Conference, Implementing Nawacita : Strategies And Policies, April-Agustus2015.

Putri, Dianingtyas Murtanti. 2013. Peran Media Online Dalam Pembangunan Provinsi Banten Journal Communication Spectrum.

Rakhmat, Jalaludin. 2003. Psikologi Komunikasi. Bandung : Remaja Rosdakarya

Renzulli, Ardha. 2012. Hubungan Faktor Kredibilitas Media Terhadap Aktivitas Akses Berita Online Berdasarkan Segmentasi Psikografis. Thesis. Universitas Indonesia.

Riduwan. 2010. Rumus Dan Data Dalam Analisis Statistika. Bandung : Alfabeta
Severin, Werner J dan James W.Tankard. 2005. Teori Komunikasi. Kencana. Jakarta.

Sugiyono. 2010. Metode Penelitian Kuantitatif, Kualitatif dan R\&D. Bandung : Alfabeta.

Tawaang, Felix. 2015. Agenda Media Suratkabar (Analisis Isi Suratkabar Ibukota)/Newspapers Media Agenda (The Capital Newspapers Content Analysis), Peneliti Bppki Jakarta Badan Litbang Sdm Kementerian Kominfo Ri, Jp Komunikasi.

Widodo, Rachmat. 2012. Skripsi. Kredibilitas Pemberitaan Pada Portal Berita Online Vivanews.Com. UNDIP.

Wood, Julia. T. 1997. Communication in Our Lives. Washington : Wadsworth Publishing Company. 